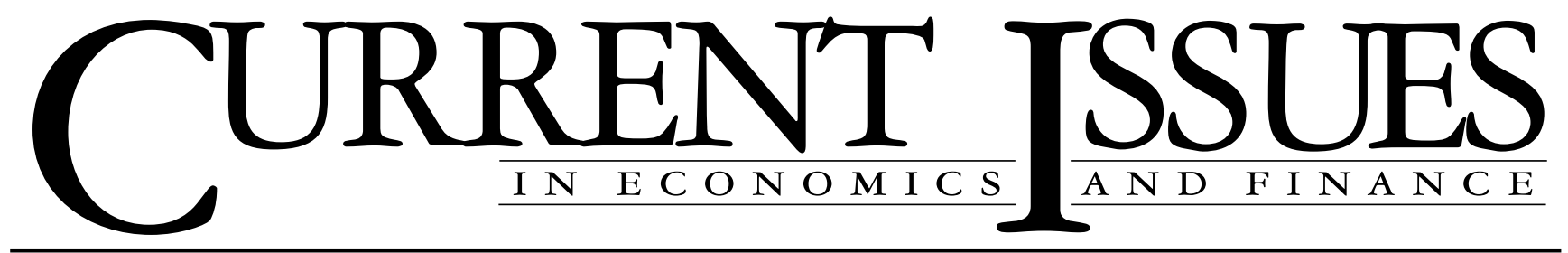

November 1995

Volume 1 Number 8

\title{
The Employment Report and the Dollar
}

Ethan S. Harris and Natasha M. Zabka

Perhaps no piece of news garners more attention in exchange markets than the U.S. employment report. Yet there has been only limited research on the market's response to the monthly release. This article quantifies the impact of the report and explains why exchange market sensitivity to the employment announcements has increased over time.

At 8:30 a.m. on the first Friday of each month, the release of the U.S. employment report triggers a flurry of activity on foreign exchange trading floors. The headline statistics - the unemployment rate and the change in payroll employment-flash across computer screens, followed by a number of secondary indicators. Economists on the trading floor shout on-the-spot assessments of how the data measure up to expectations and provide a running commentary to traders as more detail becomes available. Traders swing into action, changing their market quotes as they seek to lock in profits or contain losses on their trading positions. By the end of the day, financial reporters call trading floors to learn the market's verdict: Did the report suggest an increased risk of inflation? Did it change market expectations of the course of monetary policy? Was the exchange market's reaction influenced by developments in other financial markets? And, in view of these crosscurrents, did the dollar rise or fall?

Surprisingly, despite the market's growing focus on the employment report, virtually no published studies have attempted to quantify the response of the foreign exchange market to new information in the report (see the box on page 5 for a review of related literature). This edition of Current Issues attempts to fill this gap. Specifically, we compare the data announced in the report to the consensus forecasts of market practitioners and quantify how surprises in the report affect the major exchange markets over the trading day. Our analysis shows the following:

- On average, good news for the U.S. labor market is good news for dollar investors: an unanticipated rise in employment strengthens the foreign exchange value of the dollar.

- Traders' reactions to surprises are mainly driven by the report's implications for short-term interest rates.

- The market impact of the report has grown considerably stronger over time, particularly for the closely watched payroll employment number.

\section{What Drives the Market's Response?}

Academic theory and foreign exchange market commentary suggest that two contradictory stories underlie market responses to positive news on economic growth. ${ }^{1}$ On the one hand, an announcement of an unexpected rise in payroll employment or fall in the unemployment rate may raise fears of inflation, making dollar assets less desirable and putting downward pressure on the dollar. ${ }^{2}$ On the other hand, a strong report may signal a tightening of credit markets, partic- 
ularly if market participants believe that unexpected evidence of economic expansion increases the probability of more restrictive monetary policy. In this case, U.S. interest rates should rise relative to foreign interest rates, making dollar assets more desirable and

\section{Academic theory and foreign exchange market commentary suggest that two contradictory stories underlie market responses to positive news on economic growth.}

putting upward pressure on dollar exchange rates. Although the two stories could apply to different episodes, this article investigates which interpretation is, on balance, best supported by the data.

\section{Evidence of Market Impacts}

To explore this issue, we designed the following tests. We calculated the percentage change in six important bilateral exchange rates-the rate at which the German mark, Japanese yen, British pound, French franc, Italian lira, and Canadian dollar each trade relative to the U.S. dollar-from 4:00 p.m. the day before the report is released to 4:00 p.m. the day of the release. We then tested for the exchange rate response to four pieces of new information contained in the employment report: the unexpected change in payroll employment, the unexpected change in the unemployment rate, and two kinds of revisions to past payroll num-

\section{Chart 1 \\ Payroll Employment Growth: Actual and Consensus Forecast}

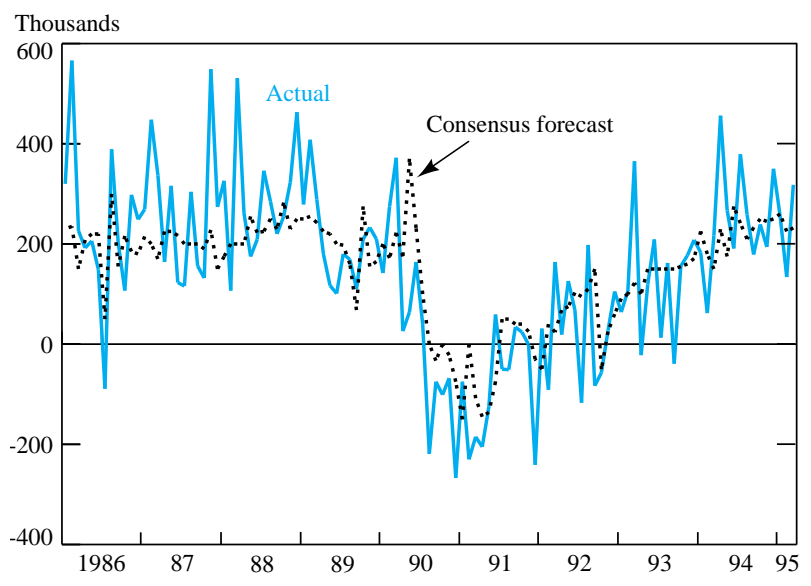

Sources: Money Market Services International, Inc.; U.S. Department of Labor, Bureau of Labor Statistics. bers-the regular revisions to the last two months of data and the annual benchmark revision. Only unexpected components are considered because, according to the "efficient markets hypothesis," exchange rates prevailing before the release of the report should already reflect all available information on the economy; thus, only new or unexpected information should move the markets.

To measure the unexpected information, we compared the actual data with the forecasts of market specialists compiled by Money Market Services International. ${ }^{3}$ An overview of the accuracy of these forecasts is provided by Chart 1, which plots the change in payroll employment along with the consensus forecast. Although the consensus forecast does a good job of tracking trends in the data, there are also significant surprises. Payroll surprises of more than 100,000 jobs (either positive or negative) occurred on about one-third of the days we studied, and surprises of more than 200,000 jobs occurred about 10 percent of the time.

How do these labor market surprises affect the exchange markets? Chart 2 gives a flavor of our findings by depicting the impact of payroll surprises on the behavior of one bilateral exchange rate-the markdollar rate. The scatter plot and the associated regression line slope up and to the right, suggesting a positive, though not very tight, relationship between payroll surprises and the mark-dollar exchange rate. For example, on February 6, 1987, the report announced

\section{Chart 2 \\ Effect of Payroll Surprises on the Mark-Dollar Exchange Rate}

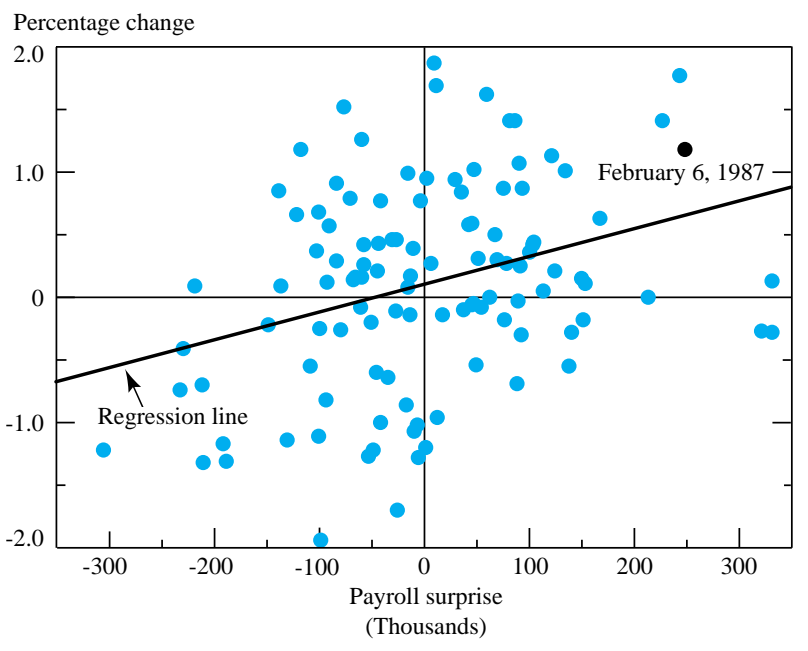

Note: Payroll surprises are calculated by subtracting expected payroll growth from actual payroll growth. 
that payroll employment had grown by 448,000 jobs, a figure far exceeding the consensus forecast of 200,000. On that same day, the mark-dollar exchange rate rose 1.2 percent. According to our regression test (represented by the regression line in the chart), about half of this rise was due to the payroll surprise.

A fuller account of our statistical results is presented in Table $1 .^{4}$ The table reports the estimated percentage response of the six exchange rates to a 100,000 job payroll surprise, a 100,000 payroll revision, and a 0.2 percentage point unemployment rate surprise. ${ }^{5}$ The table shows that positive labor market news generally strengthens the dollar:

- Unanticipated payroll employment increases have a strong positive impact on all the exchange rates (except the Canadian-U.S. dollar rate, which is discussed below).

- Annual revisions to payroll employment have a significantly positive impact on three of the exchange rates, but the regular revisions to the data from the preceding two months are never significant.

- An unexpectedly low unemployment rate pushes up the dollar, but the effects are small and generally not statistically significant.

The weaker results for the unemployment rate confirm the poor results in earlier studies that focused only on the unemployment rate. They are also consistent with the widespread market perception that payroll employment is a more accurate measure of month-to-month movements in the economy than the unemployment rate.

\section{Treasuries Hold the Key}

What is behind the market's reaction? Clearly, given the positive linkage between growth and the dollar, inflation fears must play at best a secondary or episodic role. A closer look underscores the key role of shortterm interest rates. ${ }^{6}$ As the last column of Table 1

\section{We can only conclude that a strong employment report, particularly for payroll growth, drives up the dollar because it causes a concurrent rise in short-term interest rates.}

shows, three-month Treasury interest rates are highly sensitive to payroll employment surprises. Indeed, on average, an unexpected increase of 100,000 jobs raises the three-month Treasury interest rate by 5.5 basis points. Furthermore, simple correlation tests show that while Treasury interest rates typically do not move up and down with the dollar, on employment release days there is a very strong positive correlation between these markets. For example, the correlation of the percentage change in the mark-dollar exchange rate with the change in the three-month Treasury rate is just .06 for all the days in our sample, but it rises to .40 on employment release days and to .57 on days when there is a large payroll surprise (greater than 150,000 jobs).

Although correlation does not prove causation, in this case there is little doubt that causation exists and that it runs from interest rates to the dollar rather than

\section{Table 1}

Estimated Impact of Labor Market Surprises on Bilateral Exchange Rates

\begin{tabular}{|c|c|c|c|c|c|c|c|}
\hline \multirow[b]{2}{*}{ Surprise } & \multicolumn{6}{|c|}{ Percentage Change } & \multirow{2}{*}{$\begin{array}{c}\text { Impact on } \\
\text { Three-Month } \\
\text { Treasury Rates }\end{array}$} \\
\hline & DM-US\$ & $¥$-US\$ & Can\$-US\$ & $£$-US\$ & F-US\$ & Lit-US\$ & \\
\hline \multicolumn{8}{|l|}{ Increase of 100,000 payroll jobs } \\
\hline Current month & $0.20 * * *$ & $0.12 * *$ & 0.00 & $0.17 * *$ & $0.17 * * *$ & $0.15 * * *$ & $5.5 * * *$ \\
\hline Monthly revisions & -0.06 & -0.01 & 0.02 & 0.08 & -0.08 & -0.15 & 1.4 \\
\hline Annual revision & $0.11 * *$ & 0.04 & -0.00 & 0.08 & $0.10 *$ & $0.09 * *$ & 0.0 \\
\hline 0.2 change in unemployment rate & -0.07 & -0.04 & $-0.09 * *$ & -0.04 & -0.04 & -0.10 & $2.0^{*}$ \\
\hline Overall fit $\left(\mathrm{R}^{2}\right)$ & 0.16 & 0.07 & 0.07 & 0.09 & 0.11 & 0.15 & 0.56 \\
\hline
\end{tabular}

Note: The sample includes the 111 days on which the monthly labor market report was released between January 1986 and March 1995 . The dependent variable is the percentage change in the exchange rate from the market closing (4:00 p.m., New York time) the previous day to 4:00 p.m. the day of the release. The change in the three-month Treasury rate is measured in basis points.

*Significant at the 10 percent level.

**Significant at the 5 percent level.

*** Significant at the 1 percent level. 
the other way around. Rising interest rates would logically drive up the dollar by making dollar assets more attractive. By contrast, a strengthening dollar, in and of itself, is highly unlikely to cause short-term interest rates to rise. Indeed, a strong dollar tends to weaken the economy, lowering inflation risks and putting downward pressure on interest rates. We can only conclude that a strong employment report, particularly for payroll growth, drives up the dollar because it causes a concurrent rise in short-term interest rates.

\section{Payroll Power Grows}

Our analysis shows not only that payroll employment growth has market-moving power, but also that its potency has grown over time. An unexpected 100,000 job increase in the 1991-95 period had roughly three times more market impact than in the $1986-90$ period (Table 2). This finding probably reflects two factors. First, it is consistent with the fact that payroll employment is increasingly viewed as the key monthly indicator. Second, the finding may reflect a reduced effort to manage exchange rates in the more recent period. ${ }^{7}$ The earlier period was marked by two major exchange rate accords, the Plaza Accord of 1985 and the Louvre Accord of 1987, which were both designed to steer the dollar in a desired manner. The absence of similar agreements in recent years may have led market participants to conclude that monetary authorities now give less weight to exchange rates in formulating their policy responses to economic news.

\begin{tabular}{|c|c|c|c|}
\hline \multirow[b]{2}{*}{ Exchange Rates } & \multicolumn{2}{|c|}{ Percentage Change } & \multirow{2}{*}{$\begin{array}{l}\text { Change } \\
\text { Significant? }\end{array}$} \\
\hline & $1986-90$ & $1991-95$ & \\
\hline DM-US\$ & 0.10 & $0.38^{* * * *}$ & Yes** \\
\hline ¥-US\$ & 0.06 & $0.25^{* * * *}$ & Yes* \\
\hline Can\$-US\$ & -0.02 & 0.03 & No \\
\hline$£$-US\$ & 0.08 & $0.33 * *$ & Yes* \\
\hline F-US\$ & 0.08 & $0.34 * * *$ & Yes** \\
\hline Lit-US\$ & 0.05 & $0.31 * * *$ & Yes** \\
\hline $\begin{array}{l}\text { Memo: } \\
\text { Treasury bill } \\
\text { (change in basis points) }\end{array}$ & $4.1 * * *$ & $5.5 * * *$ & No \\
\hline
\end{tabular}

*Significant at the 10 percent level.

$* *$ Significant at the 5 percent level.

***Significant at the 1 percent level.

\section{Why Doesn't Canada Conform?}

We saw earlier that the Canadian-U.S. dollar rate is the only bilateral rate immune to payroll surprises (Table 1). Why the anomalous result?

The explanation lies in Canada's close economic ties to the United States. The United States is Canada's most important trading partner, accounting for 80 percent of its exports and imports. This relationship means that Canadian monetary authorities and credit markets must pay close attention to both the strength of the U.S. economy and the bilateral exchange rate. Over our sample period, Canada did not formally target its exchange rate to the U.S. dollar, but it did carefully monitor U.S. economic developments. A strong U.S. employment report would engender several kinds of inflation risks for Canada:

- it implies increased demand for Canadian products from its most important export market;

- it could proxy for labor market strength in Canada; and

- if it prompted U.S. interest rates to rise and the U.S. dollar to appreciate against the Canadian dollar, it could lead to rising import prices.

For all these reasons, the release of a favorable U.S. employment report could push up Canadian short-term interest rates as well as U.S. rates. Table 3 shows the impact of the U.S. report on Canada's three-month commercial paper rate. Although much of the impact is delayed until the day after the report is released, Canadian short-term interest rates respond almost as strongly as U.S. rates to U.S. payroll employment surprises. An unexpected increase of 100,000 jobs boosts Canadian rates an average of 4.6 basis points, compared with 5.5 basis points for U.S. rates. With similar interest rate responses in both countries, investors have little reason to shift from one currency to the other. Consequently, the Canadian-U.S. dollar exchange rate remains unchanged in the face of U.S. payroll employment surprises. ${ }^{8}$

\section{Table 3 \\ Estimated Impact of U.S. Employment Surprises on Three-Month Canadian Interest Rates

\begin{tabular}{lccc} 
& \multicolumn{2}{c}{ Rate of Change in Basis Points } \\
\cline { 2 - 4 } Labor Surprise & $\begin{array}{c}\text { Day of } \\
\text { Release }\end{array}$ & $\begin{array}{c}\text { Day } \\
\text { After }\end{array}$ & $\begin{array}{c}\text { Total } \\
\text { Response }\end{array}$ \\
\hline Increase of 100,000 jobs & 1.42 & $3.17 * *$ & $4.59 * *$ \\
0.2 unemployment rate change & 0.30 & -0.83 & -0.56 \\
Overall fit $\left(\mathrm{R}^{2}\right)$ & 0.022 & 0.058 & 0.061 \\
\hline
\end{tabular}

**Significant at the 5 percent level. 


\section{Conclusion}

The results presented in this article should be of interest not only to policymakers and market participants, but also to academic economists investigating exchange rate determination. A number of studies have argued that empirical models using monthly or quarterly data have very poor explanatory power. ${ }^{9}$ An underlying problem with monthly and quarterly data is that it is difficult to determine the direction of causation among the variables. By contrast, our daily data provide a relatively clean "laboratory experiment" on the determinants of exchange rates. After all, data announcements are clearly an exogenous event, or shock, to the markets, and the U.S. employment report is almost always the dominant piece of news on the day it is released. We present three pieces of circumstantial evidence that point to an important role for interest rates in exchange rate determination: (1) a significant positive link exists between payroll surprises and exchange rates; (2) interest rates and dollar exchange rates are highly correlated on employment report release days; and (3) as shown by the Canadian case, when rates rise concurrently in the United States and abroad, the dollar does not change.

\section{Notes}

1. This discussion traces the impact of a shift in the "IS curve" in the Mundell-Fleming model.

2. In market commentary, this inflation story is often tied to the bond market reaction to the report: "bond prices, which are very sensitive to any signs of accelerating inflation, can steer the direction of the dollar because international investors need to buy dollars when they want to buy United States bonds" (Bloomberg Business News 1995).
3. The consensus forecast is derived from a survey of about forty specialists from major commercial banks, brokerage firms, private consulting firms, and other institutions. The consensus is the median response of the individual surveys. The consensus data have been widely used in previous research, including all of the studies cited in the box. Formal tests show that the consensus data provide an unbiased forecast, explain more than half of the monthly variation in payroll employment, and provide better forecasts than a simple autoregressive model.

4. We conducted a number of additional tests to see how sensitive our results were to alternative specifications. First, we confirmed that the expected components of the unemployment rate and payroll growth were not statistically significant. Second, we found that all of the impact on exchange rates occurred on the day of the release and that the results were essentially the same whether the tests focused on exchange rate movements in the morning or over the course of the day. Third, using a smaller sample period (199294), we found that focusing on the initial market reaction (up to 9:00 a.m.) reduced the standard errors of the estimates but did not significantly change the point estimates. For example, in a regression of the mark-dollar exchange rate, the estimated initial response to a 100,000 job surprise was .28 percent and the full-day response was .31 percent.

5. The equation is linear. We chose these thresholds to illustrate the impact of a fairly large surprise.

6. Hardouvelis (1988) makes a similar point in his paper, noting that his finding of a generally positive response of both the dollar and interest rates to strong growth indicators is consistent with the interest rate story and is inconsistent with the inflation story.

7. For both of these reasons, we should expect the interest rate response to payroll surprises to be stronger as well. However, Table 2 shows a much smaller increase in the sensitivity of the three-month Treasury interest rate than in that of exchange rates. Three factors may be at work: (1) the dollar response to news depends on foreign as well as U.S. interest rates, and in the more recent period, foreign monetary authorities may be less concerned about matching U.S.

\section{Related Research}

Although earlier research has looked at the impact of a variety of growth indicators on exchange markets, no previous published study has taken a comprehensive look at the U.S. employment report. The mixed results of several earlier studies are summarized below:

\begin{tabular}{|c|c|c|c|}
\hline Study & Sample & $\begin{array}{l}\text { Exchange Rates } \\
\text { (Foreign Currency-U.S. Dollar) }\end{array}$ & Effects of News Variables \\
\hline Hakkio and Pearce (1985) & 1977-84 & $\begin{array}{l}\text { Mark, pound, French franc, yen, } \\
\text { lira, Swiss franc, Canadian dollar }\end{array}$ & $\begin{array}{l}\text { Of the indicators studied, only the money supply is } \\
\text { consistently significant. The unemployment rate and } \\
\text { three other variables have small, insignificant effects } \\
\text { on exchange rates. }\end{array}$ \\
\hline Hardouvelis (1988) & 1979-84 & $\begin{array}{l}\text { Mark, pound, French franc, yen, } \\
\text { lira, Swiss franc, Canadian dollar }\end{array}$ & $\begin{array}{l}\text { Of the indicators studied, only the money supply is } \\
\text { consistently significant. The unemployment rate is } \\
\text { only significant for the pound and Swiss franc. Twelve } \\
\text { other growth indicators are significant in about } \\
\text { one-fourth of the tests. }\end{array}$ \\
\hline $\begin{array}{l}\text { Moorthy (1993) } \\
\text { (unpublished) }\end{array}$ & $1985-92$ & Mark, yen & $\begin{array}{l}\text { Payroll employment has a significant impact on both } \\
\text { exchange rates. }\end{array}$ \\
\hline Puffer (1995)* & 1980-92 & Mark, pound, yen, Canadian dollar & Trade deficit announcements move the dollar. \\
\hline
\end{tabular}

*Puffer's article is the most recent in a series of studies concluding that trade deficit announcements move the dollar. 
interest rate changes; (2) market participants may have growing confidence that monetary authorities will eventually respond to the inflation signal in the employment report, even if the expected immediate response is modest; and (3) with the increased integration of international capital markets, exchange rates may be more responsive to interest rate movements.

8. There are two interesting anomalies in the Canadian response. First, as noted, Canadian rates rise with a one-day lag. This lag is inconsistent with the "efficient markets" hypothesis because Canadian commercial paper traders should be able to earn arbitrage profits by anticipating the delayed market response. Second, the Canadian dollar is significantly affected by unexpected news on the unemployment rate. The reason is that Canadian interest rates are considerably less sensitive to the U.S. employment rate than are U.S. interest rates (compare Tables 2 and 3). As a result, unemployment surprises significantly widen the U.S.-Canadian interest rate differential, putting statistically significant pressure on the dollar.

9. The original finding was by Meese and Rogoff (1983). More recently, after reviewing data for the 1970s and 1980s, Meese (1990) wrote: "The proportion of (monthly or quarterly) exchange rate changes that current models can explain is essentially zero" (p. 177).

\author{
References \\ Bloomberg Business News. 1995. Cited in "The Dollar Takes a \\ Tumble, Following U.S. Bonds Lower." New York Times, \\ February 11. \\ Hakkio, Craig S., and Douglas K. Pearce. 1985. "The Reaction of \\ Exchange Rates to Economic News." Federal Reserve Bank of \\ Kansas City Research Paper no. 8501. \\ Hardouvelis, Gikas A. 1988. "Economic News, Exchange Rates, \\ and Interest Rates." Journal of International Money and \\ Finance 7: 23-35. \\ Meese, Richard. 1990. "Currency Fluctuations in the Post-Bretton \\ Woods Era.” Journal of Economic Perspectives 4, no. 1: 117-34. \\ Meese, Richard, and Kenneth Rogoff. 1983. "Empirical Exchange \\ Rate Models of the Seventies: Do They Fit Out-of-Sample?" \\ Journal of International Economics 3, no. 24. \\ Moorthy, Vivek. 1993. "Efficiency Aspects of Exchange Rate \\ Response to News: Evidence from U.S. Employment Data." \\ Federal Reserve Bank of New York Research Paper no. 9326. \\ Obstfeld, Maurice. 1985. "Floating Exchange Rates: Experience \\ and Prospects." Brookings Papers on Economic Activity, \\ no. 2, pp. 369-464. \\ Puffer, Marlene K. 1995. "Measurement of the Unexpected U.S. \\ Trade Deficit." Journal of International Money and Finance 14, \\ no. 2: 247-73.
}

\section{About the Authors}

Ethan Harris is a research officer and senior economist and Natasha Zabka an assistant economist in the Domestic Research Function of the Research and Market Analysis Group.

The views expressed in this article are those of the authors and do not necessarily reflect the position of the Federal Reserve Bank of New York or the Federal Reserve System.

The Federal Reserve Bank of New York provides no warranty, express or implied, as to the accuracy, timeliness, completeness, merchantability, or fitness for any particular purpose of any information contained in documents produced and provided by the Federal Reserve Bank of New York in any form or manner whatsoever.

Current Issues in Economics and Finance is published by the Research and Market Analysis Group of the Federal Reserve Bank of New York. Dorothy Meadow Sobol is the editor.

Editorial Staff: Valerie LaPorte, Mike De Mott, Elizabeth Miranda

Production: Graphics and Publications Staff

Subscriptions to Current Issues are free. Write to the Public Information Department, Federal Reserve Bank of New York, 33 Liberty Street, New York, N.Y. 10045-0001, or call 212-720-6134. Back issues are also available. 